\title{
Developing and Evaluating Self Assessment Reading Competence Descriptors for the European Language Portfolio
}

\author{
JoAna Pierce And Pilar Durán \\ Technical University of Madrid
}

Received: 29 August 2012 / Accepted: 29 May 2013

ISSN: $1697-7467$

\begin{abstract}
This article describes the studies piloting the self-assessment reading descriptors to be included in the Academic and Professional European Language Portfolio for engineering and architecture students, accredited by Council of Europe. They were developed considering the Common European Framework of Reference for Languages (2001), Schneider and Lenz's (2001) guidelines, and the teaching experience of ESP teachers of the Technical University of Madrid research group DISCYT. Then, the descriptors were piloted for clarity, relevance and calibration to the CEFRL with 149 architecture and engineering students, from first to senior year. From the results, we found that the descriptors were on the whole relevant, well calibrated and fairly well written. We have detailed non successful descriptors in order to enlighten future calibration studies for ELPs self-assessment checklists, since competence descriptor lists should be kept open to suit students' needs.
\end{abstract}

Keywords: reading competence, ELP, self-assessment descriptors; reading research, evaluation.

La formulación y evaluación de los descriptores de lectura para el Portafolio Europeo de las Lenguas

RESUMEN: Este artículo describe los estudios piloto realizados para comprobar la adecuación de los descriptores de competencia lectora con anterioridad a su inclusión en el Portafolio Europeo de Lenguas Académico y Profesional encaminado a la práctica de la auto-evaluación de estudiantes de ingeniería y arquitectura, que recibió la acreditación del Consejo de Europa. Se redactaron teniendo en cuenta el Marco Común Europeo de Referencia para las lenguas (2001), las directrices de Schneider y Lenz (2001) y la experiencia docente del profesorado de IFE de la Universidad Politécnica de Madrid que forman parte del GI DISCYT. Las propiedades de los descriptores estudiadas fueron claridad, relevancia y equiparación con los niveles de referencia del MCERL; 149 alumnos desde el primero al último curso participaron. Con los datos obtenidos constatamos que los descriptores resultaban claros y relevantes y aceptablemente bien calibrados. Hemos detallado las razones para rechazar ciertos descriptores con el fin de iluminar la redacción de otros que puedan formar parte de nuevas listas de auto-evaluación, ya que estas deben permanecer abiertas a las necesidades de los alumnos.

Palabras clave: competencia lectora, PEL, descriptores para la autoevaluación, investigación en habilidad lectora, evaluación. 


\section{INTRODUCTION}

Ensuring that all European graduates are proficient in at least one or two languages, other than their mother tongue, implies a powerful challenge to educators. For this reason, it is necessary for higher education institutions to evaluate their language teaching practice critically in the light of the academic and professional context for which they are preparing their students, and of the role of languages within this context.

One of the aims of higher education is to make learners more self-reliant. The ability to work autonomously, that is, the ability to organize available time, choose priorities, work to deadlines and deliver what has been agreed on, is essential for engineering students' personal and professional life (Duran and Pierce, 2007). Furthermore, the development of language awareness that allows students to take part in the objectives, processes and assessment of learning is also essential (Cheng, 2006).

Responding to this new paradigm, the research Group DISCYT ${ }^{1}$ developed an Academic and Professional European Language Portfolio (ACPEL Portfolio) ${ }^{2}$ (Duran et al., 2009) to meet the needs of the more mobile students, which takes into special account the requirements of the academic and professional environment of engineers and architects. A repeated complaint among university instructors throughout Europe, including Madrid Technical University language teaching staff, was that the existing versions of the European Language Portfolio (ELP) were too general in scope and did not take into account the special aspects of language learning and use in the technical university context (Pierce and Ubeda, 2006; Pierce and Robisco, 2010). Specifically in Spain, when we started the project three versions of the ELP were validated, all three published by the Ministry of Education. The ELP's were targeted respectively to students of primary education, secondary education and adults. The adult version is very much oriented to the immigrant population learning Spanish.

The work reported in this paper is part of a larger project ${ }^{3}$ which resulted in the development of the above mentioned ACPEL Portfolio targeted for the use of UPM students (Duran et al., 2009), accredited by European Language Portfolio Validation Committee of Council of Europe. In this article, we describe the results of two studies involving university students enrolled in four different degree programs at the Madrid Technical University. We were interested in evaluating the self assessment reading descriptors included in the portfolio for their clarity, their calibration to the Common European Framework of Reference (CEFR) and, finally, their relevance to architect and engineering students. The purpose of this paper is to provide an example of reading descriptors and their development and results of the piloting them with the students.

\footnotetext{
${ }^{1}$ The Universidad Politécnica de Madrid research group DISCYT is made up of nine English teaching staff from the Schools of Architecture, Agriculture, Civil Engineering, Mining, Aeronautical and Telecommunications Engineering, and Physical Education and Sports Science.

${ }^{2}$ The ACPEL Portfolio is a bilingual version of the ELP in English and Spanish, for higher education and professional language learners' purposes. The ELP Validation Committee has granted this model the accreditation number 98.2009, www.coe.int/portfolio, (info@mairea-libros.com) .

${ }^{3}$ This work was supported by the Madrid Technical University and Madrid Regional Government (PC05/11129. IV PRICYT).
} 
Our external framework for calibration has been the CEFR, developed by the Council of Europe in order to promote transparency and coherence in language learning and teaching in Europe (García Doval et al., 2004). The CEFR has proved most useful for the planning and the development of curricula as well as for the development of tests and examinations for certification. It provides a practical tool for setting fairly clear standards to be attained at successive learning stages and for evaluating outcomes in an internationally comparable manner. Language competence is divided into six levels clustering into three bands: A1-A2 (basic user), B1-B2 (independent user), and C1-C2 (proficient user). Each level provides illustrative scaled checklists of "I can" descriptors in the form of verbal "can-do statements" relating to five language skill areas: listening, reading, spoken interaction, spoken production and writing. The existence of such levels presupposes that "descriptions of a particular degree of skill belong to one level rather than another" (CEFR, 2001:207), and that there are shared criteria to do so, following intuitive, qualitative and quantitative methods, as we shall describe later.

Shortly after the implementation of the CEFR, a second instrument was initiated, the European Language Portfolio (ELP), "the CEFR's companion piece" in David Little's words (Little, 2009:1). The aim of the ELP is to educate students to become autonomous, life-long language learners that can realistically assess their proficiency in the different language skills and can communicate this to institutions for further education, employers and other interested parties. Portfolios have been used internationally to aid teaching and learning of second languages stressing autonomous learning, personal learning styles, strategic learning and self-assessment practices (Johns, 1997, Yang, 2003).

The ELP is made of 3 parts: Language Passport which describes the holders' abilities by skill (speaking, reading, listening, writing) for reflection and assessment; the Language Biography, which is used to describe the holder's experiences in each of the languages, and is intended to serve as a guide for learners in planning and evaluating their progress; and the Dossier which contains examples of personal work to illustrate language skills and abilities (Morrow, 2004). The purpose of the ELP is to make the language learning process more transparent to the learner by making him/her responsible for self assessment, fixing objectives and planning future learning.

\section{ReAding AND SELF ASSESSMENT}

Reading can be considered as the most difficult language skill to assess. Eskey (2005: 572) reminds us that "beyond a certain minimal competence, there is no general proficiency in reading, every reader being more proficient at reading some texts than others. Within the context of higher education students, specific knowledge in scientific and technical topics becomes a highly important variable in reading comprehension, which shows that the construction of meaning lies not exclusively in the text (internal coherence), but also in the receiver's previous knowledge interpreting the printed words (external coherence) (Durán, 2001). Shohamy (1984) calls for multiple measures to be used for testing reading comprehension. One of the problems of reading is that the processes are internal, hidden, and abstract. Self assessment can aid in making the hidden processes more external and visible, allowing $\mathrm{him} / \mathrm{her}$ to develop their inner measure of progress. The learner should therefore be given 
the opportunity of participating in the assessment process since the learners' own knowledge of their own experience with the language is necessarily more extensive than what anyone else may recognize or be able to judge (Pierce, Duran and Ubeda, 2011).

Bachman and Palmer (1989) found self-ratings to be more reliable than they expected but, as Ross (1998) discusses in a review of studies, self-assessments correlate very differently across skills, with reading correlating more strongly than listening, speaking and writing. Self-assessments of reading therefore tend to produce more valid results than selfassessments of the other three skills. Duran and Pierce (2010) performed a study with first year mining students which involved students self assessing their competencies in reading, writing, and listening. Although there were discrepancies between the Oxford placement test and self assessment, on the whole, students were roughly accurate when assessing their reading skills . Also, as found in Ross's review, reading correlated more strongly than listening and writing. When the bands were bands joined together in our study that is, joining A1 with A2, B1 with B2, the correlations are very strong (Table 1).

Table 1. Comparison of Oxford placement with reading self assessment

\begin{tabular}{|l|c|c|c|}
\hline & A1-A2 & B1-B2 & C1-C2 \\
\hline Oxford placement & $56 \%$ & $44 \%$ & $0 \%$ \\
\hline Self assessment -reading & $52 \%$ & $46 \%$ & $2 \%$ \\
\hline
\end{tabular}

\section{Developing, Calibrating ANd ADAPTing ReAding Descriptors}

\subsection{The process of developing descriptors}

It is a generally accepted notion that the selection and ordering of the language learning reading objectives may vary enormously depending on the context, the target group and the level of the readers. Furthermore, as the CEFR (2001:170) points out, "it should be stressed that objectives for the same type of public in the same context and at the same level could also vary regardless of the weight of tradition and the constraints imposed by the education system". This is particularly true of higher education reading materials and objectives applied to engineering students.

The reading descriptors were developed according to guides set out by Lenz and Schneider (2004). A good descriptor should embrace the following characteristics: positive, definite, clear, brief, and independent (i.e., it does not depend on another descriptor at same level). It should be formulated by using positive descriptions of what the learner can do in describing concrete tasks or degrees of skill; it should be written in clear simple language, which does not require any previous training; and, finally, the descriptors should be independent of each other and be answerable with a clear "I can do this" or "I can't do this". Problematic descriptors lack precision, may be too complicated syntactically, use uncommon vocabulary and rely on idiomatic speech for understanding (Pierce and Robisco, 2010).

As we have said, the CEFR descriptive scheme and the general language reference levels provide a conceptual grid that can be used as a guideline to describe new specific 
systems, which should all refer to the six levels mentioned above. Accordingly, all scales of language reference levels should meet certain criteria that may be summarized as follows (Council of Europe, 2001).

They should be context-free in order to accommodate more general results from specific contexts, while being context-relevant. In other words, the categories used to describe what learners can do in different situations of language use must be relevant to the target contexts of use of the different groups of learners within the overall target population, i.e. they should take specific contexts into account, but they should be, as the same time, gerneralizable within such contexts.

The scale description needs to be based on theories of language competence while simultaneously remaining user-friendly. This is to say that whereas the categorization and description needs to be theoretically grounded, it must also remain accessible to practitioners from the target population. This is difficult to achieve and it has required piloting the descriptors with the students in order to test their readability and improve their wording whenever necessary. In order to motivate self-guided autonomous learning, students cannot be put off by complicated descriptors which are difficult to understand.

Checklists such as the ones developed in the Swiss National Science Foundation Project (http://culture2.coe.int/portfolio/inc.asp) are good examples of well developed descriptors. In regard to definiteness, scales of descriptors or checklists work best when the descriptors contain not only what the learners can do but also how well they can do it. That is, they include both the description of the communication skill as well as its level of proficiency. Kaftandjieva and Takala (2006) provide a mapping for guiding the levels of the descriptors. It can be seen in figure 1.

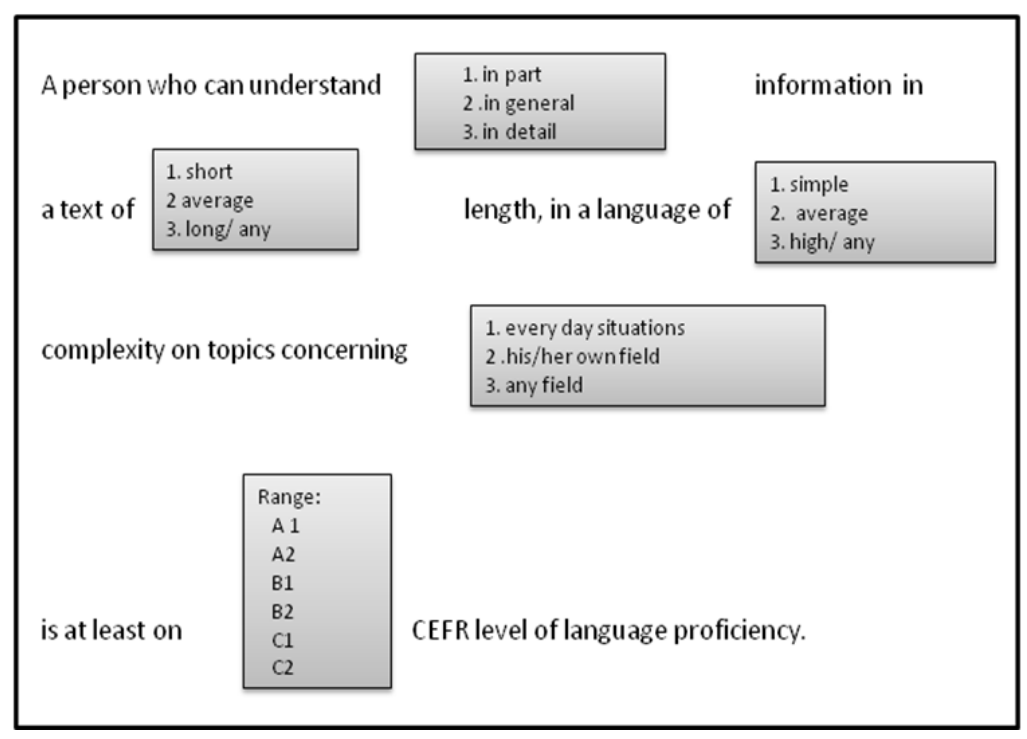

Figure 1. Guide for descriptor level 
Hence, the complexity of topics should be gradually introduced: from everyday familiar matters to more abstract open; vocabulary range should progress from basic high frequency words to a wide range of lexical accuracy; fluency from much pausing to a natural effortless style (Table 2).

Table 2. Level, key words and expressions for developing descriptors

(Durán and Cuadrado, 2007: 114)

\begin{tabular}{|c|l|l|l|l|}
\hline \multicolumn{1}{|c|}{ Thematic areas } & \multicolumn{1}{|c|}{ Vocabulary } & \multicolumn{1}{|c|}{ Fluency } & \multicolumn{1}{|c|}{$\begin{array}{c}\text { Length / style / } \\
\text { complexity }\end{array}$} \\
\hline A1 & $\begin{array}{l}\text { Familiar matters, } \\
\text { everyday objects, perso- } \\
\text { nal details }\end{array}$ & Basic, every day & $\begin{array}{l}\text { Short utterances, } \\
\text { much pausing, simple } \\
\text { messages }\end{array}$ & $\begin{array}{l}\text { Very short, phrases, } \\
\text { sentences; } \\
\text { Very simple }\end{array}$ \\
\hline A2 & $\begin{array}{l}\text { Immediate relevant, fa- } \\
\text { miliar everyday topics, } \\
\text { everyday aspects }\end{array}$ & $\begin{array}{l}\text { High frequency voca- } \\
\text { bulary, basic commu- } \\
\text { nicative needs, familiar } \\
\text { situations }\end{array}$ & $\begin{array}{l}\text { Frequent pausing, short } \\
\text { social exchanges, } \\
\text { Simple texts }\end{array}$ & $\begin{array}{l}\text { Short, brief, } \\
\text { Simple paragraphs }\end{array}$ \\
\hline B1 & $\begin{array}{l}\text { Work, study, fields of } \\
\text { interest }\end{array}$ & $\begin{array}{l}\text { Sufficient work, travel } \\
\text { and study vocabulary }\end{array}$ & $\begin{array}{l}\text { Pausing, generally } \\
\text { intelligible }\end{array}$ & $\begin{array}{l}\text { Simple essays on } \\
\text { topics of interest. } \\
\text { Clear }\end{array}$ \\
\hline B2 & $\begin{array}{l}\text { Contemporary pro- } \\
\text { blems, own special field }\end{array}$ & $\begin{array}{l}\text { Adequate use, high } \\
\text { lexical accuracy, use of } \\
\text { specific terms }\end{array}$ & $\begin{array}{l}\text { Remarkable fluency, } \\
\text { confidently, sponta- } \\
\text { neously }\end{array}$ & $\begin{array}{l}\text { Clear, } \\
\text { quite coherent, well- } \\
\text { structured }\end{array}$ \\
\hline C1 & $\begin{array}{l}\text { Highly specialised sour- } \\
\text { ces, professional }\end{array}$ & $\begin{array}{l}\text { Adequate use, wide ran- } \\
\text { ge, use of specific terms, } \\
\text { and figurative language }\end{array}$ & $\begin{array}{l}\text { Almost effortlessly, } \\
\text { clearly, accurate }\end{array}$ & $\begin{array}{l}\text { Long, elaborate, } \\
\text { coherent } \\
\text { Adequate register }\end{array}$ \\
\hline C2 & Any source, any topic & $\begin{array}{l}\text { Good command, con- } \\
\text { sistently correct, use of } \\
\text { specific terminology and } \\
\text { figurative language }\end{array}$ & $\begin{array}{l}\text { Natural, effortless, free } \\
\text { of error, appropriate(ly) }\end{array}$ & $\begin{array}{l}\text { Lengthy, complex, } \\
\text { clearly organised } \\
\text { Adequate register }\end{array}$ \\
\hline
\end{tabular}

The process of developing the descriptors underwent several phases. First, the bank of descriptors was consulted to select context-specific achievement-oriented descriptors. Many descriptors were selected and then adapted to fill our students' needs. The existing descriptors, since they are already calibrated to the CEFR levels, were extremely enlightening to the research group in that they provided models for the newly formulated ones (Lenz and Schneider, 2004). Simultaneously, members of the research group (all experienced language teachers) adapted and formulated new descriptors. Reasons for adaptations were to adjust the descriptors to a specific context, e.g. compatibility with curricula, to tailor the descriptors to specific domains of use (work, study), or to make the descriptors more easily comprehensible for lower level learners.

Then, new descriptors were mainly formulated in order to fill gaps found for certain tasks or aspects/components of tasks relevant to the curricula. One set of descriptors for each skill: speaking, listening, and writing, reading and working with texts was developed. 
For the skill of reading, 64 learning descriptors were selected, adapted, or formulated, which were then classified into seven categories:

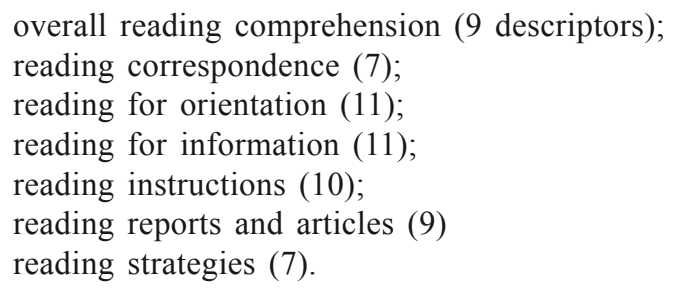

The reading descriptors underwent two different studies at this point. One was to pilot them for clarity. The second study dealt with their calibration to the CEFR levels, and their relevance.

\section{The INFORMANTS}

A total of 149 students agreed to partake in these studies and completed all the requirements of taking the Oxford Placement Test and filling out the check lists of reading descriptors. They came from four different degrees: 29 from architecture, 11 from technical architecture, 60 from technical mining engineering and 49 students from mining engineering. Technical degrees are three year degrees, while Architecture and Mining engineering degrees are currently five years.

At the beginning of the semester, students were given the Oxford Placement Test. This test was selected because of its easy delivery, and because the resulting scores are calibrated to the levels of the CEFR. We were relieved to see the informants fell into the six levels, A1-4\%, A2 34\%, B1 36\% B2 19\%, C1-C2 7\%, with the majority placed within the B1-B2 band. This distribution provided us with the opportunity to pilot the descriptors from all levels.

Although the number of students in this study is relatively small (149), the Oxford Placement Test has been given over the years throughout the schools at the UPM and we have been able to see that these findings are quite representative of the whole student population. However, it is gratifying to note that each year students enter the UPM with a slightly higher level of English.

\section{RESUlts}

\subsection{The question of clarity}

From the set of reading descriptors, scaled by teachers following the CEFR's illustrative scaled 'can do' statements and Kaftandjieva and Takala (2006) mapping guide, each teacher decided which descriptors to pilot with their group of students. Since the reading descriptors' ultimate purpose is to aid the students in self assessment and the teachers in syllabus design, 
the need to develop reading descriptors that were clearly stated was of paramount importance. Students were asked to read the provisionally scaled reading checklists and mark each descriptor as clear or unclear, and to underline specific words that caused them difficulty. The descriptors marked as unclear by five or more students were taken for revision, which amounted to twenty one. In general, the words causing difficulty were replaced with a more common synonym. Other descriptors were completely revised and rewritten.

Lexical items noted by the students as causing problems were: assess, straightforward, subtle, readily grasp, leaflets, gather, skim, scan. These items hindered the comprehension of the descriptors that contained them. Examples of descriptions marked as 'difficult to understand' are the following: Eighteen students marked the B1 R33 descriptor "I can assess a writer's purpose and attitude in articles and reports" as unclear. The verb "assess" was causing the difficulty. It was reworded thus: 'I can identify the different type of articles and reports, and their purpose, within my fields of interest' (B1). A total of ten students -nine basic users and one B1- marked the B2 "I can quickly look through a manual finding and understanding relevant explanations for a specific problem". The clauses introduced by the gerund are syntactically sophisticated and don't translate well into Spanish; nor does the verb + preposition "look through". The descriptor was not modified because it aimed at B2 and other proficient users. Descriptor R22 (B1.2) 'I can scan longer texts in my field to gather information from different texts or parts of a text in order to complete a specific task' was only marked by $25 \%$ of the students as reached. Many of them had marked the word 'scan' as difficult to understand, and others said it was troublesome to read. It was simplified and reworded thus: 'I can quickly read through longer texts in my field in order to locate specific factual information'.

Often, metaphors can cause problems for the students such as the word "grasp" in the following B2 descriptor." I can read letters, faxes and e-mails, on topics within my areas of academic or professional specialty and readily grasp the essential points". It was reworded as "I can understand letters, faxes and e-mails on topics within my areas of academic or professional specialty and quickly get the essential points'. These metaphors such as "grasp" and "straightforward" may have lost their metaphoric force for the developers and reviewers but, contrarily to what was expected, they seem to be a consistent source of misunderstanding for the students (Pierce and Robisco, 2010).

\subsection{The question of calibration}

To answer the question as to whether the reading descriptors were well calibrated to the levels of the CEFR, the students were asked to read and reflect on the chosen reading descriptors for their group: It is important to note here that the students did not know the results of their Oxford placement test at this time so not as to influence their self assessment judgment. On the right of each descriptor three empty boxes were placed and the students were asked to mark only one of the three choices: 'I can do this', 'I am working on this but haven't reached it yet (either in class or personally)', or 'This is not an objective at the moment'.

Two analyses were performed on the results. First, the mean percentage of the descriptors marked as 'I can do this' by the students. As shown in figure 2, the A1 descriptors were marked as "reached" by $89 \%$ of the students, A2 by $80 \%$, B1 by $54 \%$, B2 by $37 \%$, and C1-C2 by $35 \%$ (Figure 2). The consistent downward progression of the results suggests that 
the descriptors were well calibrated as a whole, responding to the criterion of reading ability in terms of the common framework: the higher the level of difficulty of the reading skill, the less students marked it as 'I can do this'. Therefore, this can be taken as an indicator that, generally speaking, the descriptors are well calibrated.

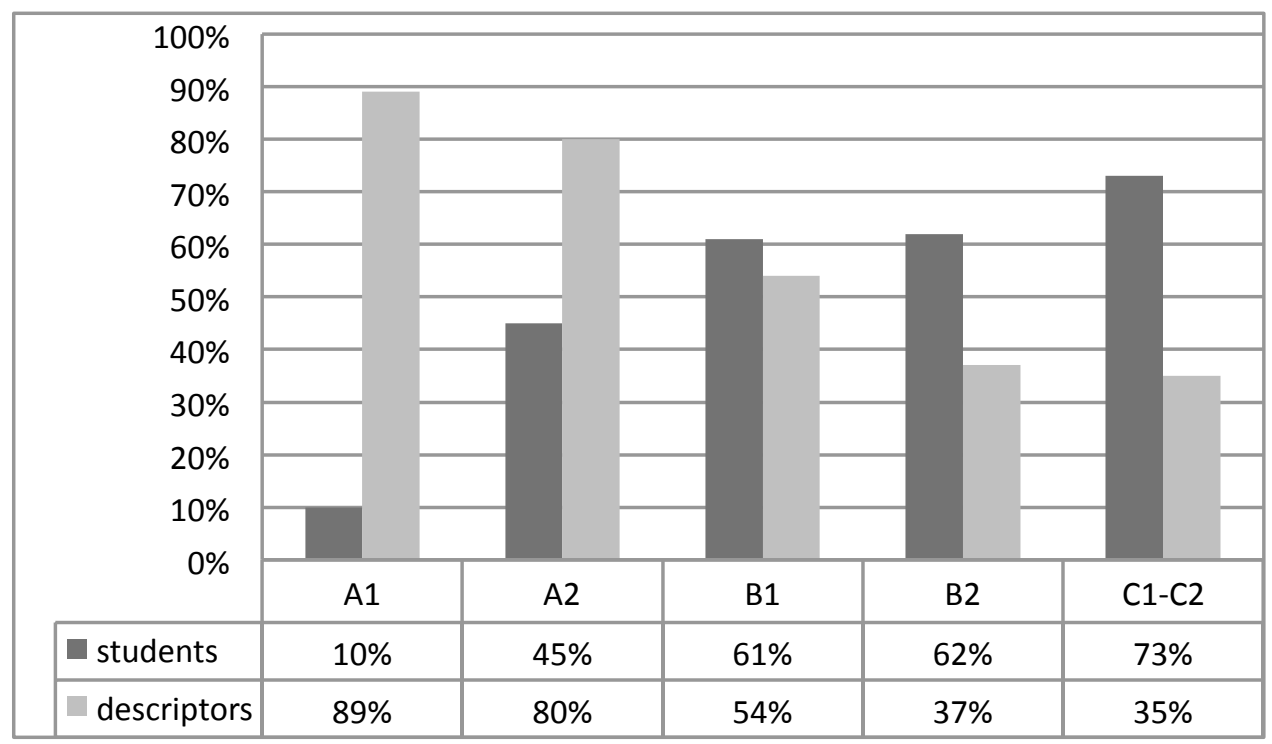

Figure 2. Mean percentage of descriptors marked "I can do this" by mean level for students and descriptors

Furthermore, if we analyze the results of the mean percentage of descriptors marked by students at each level we can see that the percentage of descriptors marked as 'I can do this' have an ascending tendency (Figure 2). Thus, A1 students marked $10 \%$ of the descriptors, A2 students marked $45 \%$ of the descriptor as reached, and so on. Again we can see that the higher the CEFR level of the students, the more reading descriptors were marked as 'I can do this'.

Apart from these global analyses, the results of the calibration for each descriptor were scrutinized by comparing the percentage of students marking it "I can do this" and the level of the descriptor. We found that A1 descriptors marked as "I can do this" ranged from $79 \%$ to $95 \%$; A2 from $64-\%$ to $92 \%$; B1 from $25 \%$ to $87 \%$; B2 from $15 \%$ to $63 \%$; C1 from $9 \%$ to $51 \%$ and $\mathrm{C} 2$ from $0 \%$ to $15 \%$. Descriptors falling on the outer ranges for each level were targeted for reconsideration of their scale according to CEFR levels.

In the appendix, we have included the draft list of the reading descriptors numbered R1 to R64, which were piloted with their respective percentages for students marking "I can do this" and "I am working on it". As an example let us look at the calibration process followed by item R30. We had given the descriptor 'I can understand the main points in 
short newspaper articles about current and familiar subjects' a B1.1 level. We found that more than $98 \%$ of the students of levels A2 onwards marked descriptor R30 as 'I can do this'. This propelled us to lower the calibration to A2.2. The following B1.1 reading descriptor was also re-calibrated to A2 because of the high percentage of students of levels A2 onwards marking it as being able to accomplish it (87\%): R14 (B1.1) 'I can understand simple messages, standard letters and e-mails'.

A surprising result was that $56 \%$ of the students leveled at A2 and higher marked the R16 'I can understand any correspondence given the occasional use of a dictionary', a C1 descriptor, as reached. If this descriptor was removed the top range decreases to $29 \%$. The key word in this objective is any correspondence. Perhaps the students interpreted correspondence to mean letters, e-mails, postcards, etc, and did not contemplate more complicated types of correspondence. Nevertheless, we decided not to introduce any changes in this case.

\subsection{The question of relevance}

By relevance here we understand the importance, usefulness and applicability of the 'can do' statements to the students' different language learning processes and situations. This is the main reason why we consulted students from first to senior year, and with all language levels, from A1 to $\mathrm{C} 2$. So, our question was: Is the descriptor a target area for the students at that moment?

To answer the question, two analyses of the student responses in the reading checklist were undertaken. First, the mean percentage of the results for column 3 'This is not an objective at the moment', were calculated for the descriptors at each level. The ticking of column 3 could be interpreted as having the least interest for the students, at the time of filling out the questionnaire

Figure 3 shows the results of the analysis. We can see, as was expected, that the higher level descriptors were marked as not an objective at the moment by a higher percentage of students. If we take into account that the greater majority of students falls under the A2, B1 and B2 levels, the results make sense: students were working towards the immediate next level, i.e. B1, B2, and C1 respectively, leaving some $\mathrm{C} 1$ and more $\mathrm{C} 2$ descriptors of reading skills for a later time. 


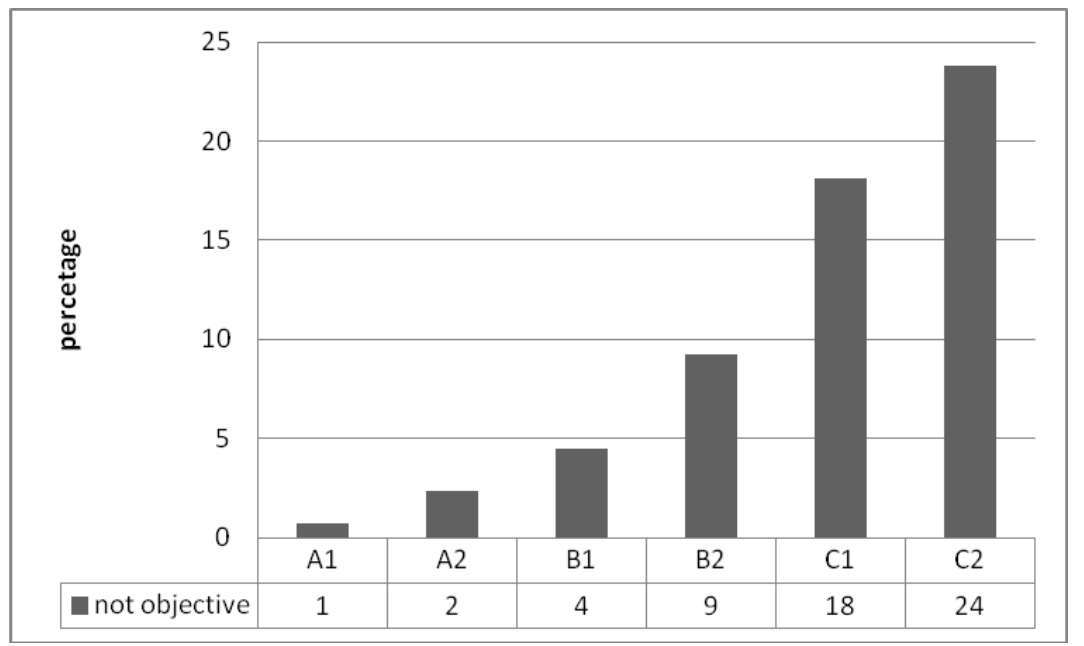

Figure 3. Results of "It is not an objective at the moment"

Then, the descriptors were scrutinized more closely and ranked according to the total percentage of students marking the item as not an objective at the moment. Three descriptors were targeted for revision in this analysis. R18, A2 descriptor 'I can skim small advertisements in newspapers, locate the heading or column I want and identify the most important pieces of information (price and size of apartments, cars, computers)' was marked by $6 \%$ as not being an objective at the moment. This percentage was considered very high compared to the other A2 descriptors that fell between 1\% and 3\%. Analyzing the descriptor, we saw that it breaks the rule for briefness and possible clearness, two of criteria of a well written descriptor. The descriptor was removed.

Two other descriptors stood out in this analysis marked by $11 \%$ and $10 \%$ of the students respectively. R53, B1 'I can recognize the different parts of engineering reports and articles: abstract, introduction, methods, discussion, conclusions, acknowledgements and references', and R33 B1, 'I can assess a writer's purpose and attitude in articles and web pages'. The first one is very connected to specific course content which may or not have been included in the courses of the students piloted. It is then very natural that such a high percentage of the students mark it as not an objective. The other descriptor contains the problematic word assess, as we said before, and describes an action which may not be considered by the students as important. Many of the students who piloted the descriptors were first year students who may not know the importance of knowing the writers purpose and attitude when reading.

The number of students marking this column is much lower than the other two columns 'I am working on this' and 'I can do this'. Therefore we can then assume that the descriptors are considered relevant by the students.

Once the descriptors were analyzed, the research team considered that some of them could be left out, either because their wording was not clear, because it was not relevant for a representative high percentage of the students, or because they were repetitious. We 
started with 64 items and, at the end we left 51 reading skill descriptors in the final self assessment check list.

\section{Concluding Remarks}

In this article, we have described the results of two studies piloting 64 reading descriptors to be included in the ACPEL Portfolio. Lenz and Schneider (2004) had recommend five procedures to be followed when developing descriptors (1) collective judgment by teaching staff concerned; (2) the selection of the most promising items for piloting (3); calibration of the descriptor by the teaching staff (4); rephrase the descriptors and eliminate some if necessary (5) to ensure the suitability of the descriptors before their incorporation into the checklists. Our procedure went one step further by using the students as informants as to the clarity, calibration and relevance of the descriptors. We consider the inclusion of higher education students' opinions and their language level of great importance at this point, since reading competence descriptors are meant to aid them in their self evaluation practices.

With the involvement of experienced educators and students enrolled at our Engineering Schools, our aim has been to detect those reading descriptors which were unclear, and not well calibrated in accordance with the CEFR, in order to rewrite and to refine them. We have detailed non successful descriptors in order to enlighten future calibration studies for ELP's self-assessment checklists, since competence descriptor lists should be kept open to suit students' needs. Additionally, we have tried to determine which factors are involved in a well-written well-calibrated descriptor. We found that the descriptors were on the whole well calibrated and fairly well written. A large majority of the descriptors were found adequate and useful for the English for Specific Purposes teachers as well as for the students. Using the students as informants has greatly improved the ACPEL portfolio and especially the self-assessment reading descriptors.

\section{REFERENCES}

Bachman, L.F. and Palmer, A.S. (1989). "The construct validation of self ratings of communicative language ability", in Language Testing 6 1, 14-29.

Cheng, A. (2006). "Understanding learners and learning in ESP genre-based writing instruction", in English for Specific Purposes 25, 76-89.

Council of Europe 2001. Common European framework of reference for languages: Learning, teaching and assessment. Cambridge: Cambridge University Press

Durán, P. (2001). "Funciones de la lectura en la enseñanza del Inglés Profesional y Académico. Estrategias de comprensión lectora", in Didáctica. Lengua y Literatura 13, 69-85.

Durán, P. and Cuadrado G. (2007). "Developing language descriptors to match the writing competence of engineering students", in A.M. Bocanegra, M.C. Lario, and E. López, E. (eds.) English for Specific Purposes: Studies for Classroom Development and Implementation. Cádiz: Universidad de Cádiz 105-124.

Durán, P. and Pierce J. (2007). "An EAP literacy portfolio for tertiary education students: Academic and professional discourse development within the European framework of reference 
for languages", in A. Curado, P. Edwards and M. Rico (eds.), Approaches to Specialized Discourse in Higher Education and Professional Contexts. Newcastle: Cambridge Scholars Publishing, 182-197.

Durán, P. and Pierce J. (2010). "Self assessment based on language learning outcomes: a study with first year engineering students", en Revista Alicantina de Estudios Ingleses 23, 133-148.

Durán, P., Cuadrado, G., Pierce, J. Roldán, A. Robisco, M. Santiago, J. and Úbeda, P. (2009). Portfolio Europeo de las Lenguas Académico y Profesional. ACPEL Portfolio y Banco de Descriptores de Destrezas Comunicativas Profesional y Académico. Madrid: Endymión.

Eskey, D.E. (2005). "Reading in a second language", in E. Hinkel (ed.), Handbook of Research in Second Language Teaching and Learning. Mahwah, NJ.: Lawrence Erlbaum, 563-579.

García Doval, F.; Guillén, C., González Piñeiro, M., Gionzález Porto, J., Serna, I., Vez, J.M., (2004). "Marco y Portafolio: Porta Linguarum para los europeos", en Porta Linguarum 2, 69-92.

Johns, A.M. (1997). Text, Role and Context: Developing Academic Literacies. New York: C.U.P:

Kaftandjieva F.and Takala S. (2006) The mapping sentence guide to the galaxy of "can do's. Accessed October 7, 2007 www.ealta.eu.org/conference/2006/docs/Kaftandjieva\&Takala_ ealta2006.ppt

Lenz, P. and Schneider, G. (2004). Introduction to the bank of descriptors for self-assessment in European Language Portfolios. Accessed July 7, 2006 from Council of Europe web site: www.coe.int/T/DG4/Portfolio/documents/Introduction_descriptor.doc

Little, D. (2009). The European Language Portfolio: where pedagogy and assessment meet. DGIV EDU LANG 2009: 19. Strasbourg, Council of Europe.

Morrow, K. (2004). Insights from the Common European Framework. Oxford: Oxford University Press.

Pierce, J., Durán P., and Úbeda, P. (2011). "Alternative assessment in engineering language education: the case of the Technical University of Madrid", in US-China Education Review $8,2,179-187$.

Pierce, J. and Robisco, M. (2010). "Evaluation of oral production learning outcomes for higher education in Spain", in Assessment and Evaluation in Higher Education 35, 6 745-758.

Pierce, J. and Úbeda, P. (2006). "The European Language Portfolio: review of the implementation in higher education." Proceedings of the XXIV International Congress of the Spanish Association of Applied Linguistics Madrid: UNED, 991-997.

Ross, S. (1998). "Self-assessment in second language testing: a meta-analysis and analysis of experiential factors", in Language Testing 15 1, 1-20.

Rumelhart, D.E. and Ortony, A. (1977). "The representation of knowledge in memory", in R.C. Anderson, R.J. Spiro and W.E. Montague (eds.) Schooling and the Acquisition of Knowledge. Hillsdale, N. J.: Lawrence Earlbaum, 21-34.

Schneider G. and Lenz P. ( 2001). European Language Portfolio: Guide for Developers. Strasbourg, Council of Europe.

Shohamy, E. (1984). "Does the testing method make the difference? The case of reading comprehension", in Language Testing 1, 147-70.

Yang, Nae-Dong (2003). "Integrating Portfolios into learning strategy-based instruction for EFL college students", in International Review of Applied Linguistics in Language Teaching, 41: 4, 293-318. 


\section{APPENDIX \\ Self assessment reading check list}

\begin{tabular}{|c|c|c|c|c|}
\hline \multicolumn{3}{|c|}{ OVERALL READING COMPREHENSION } & \multirow{2}{*}{ 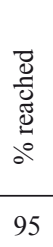 } & \multirow{2}{*}{ 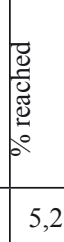 } \\
\hline R 1 & A1 & I can understand very short, simple texts recognising words and basic phrases & & \\
\hline $\mathrm{R} 2$ & A2 & $\begin{array}{l}\text { I can understand short, simple, concrete texts on academic, familiar or job- } \\
\text { related matters containing common words. }\end{array}$ & 87 & 13 \\
\hline R 3 & B1 & $\begin{array}{l}\text { I can read straightforward factual texts on subjects related to my field of } \\
\text { interest with a reasonable level of understanding within my academic and } \\
\text { professional field. }\end{array}$ & 57 & 41 \\
\hline R 4 & B1 & $\begin{array}{l}\text { I can understand in detail academic and professional texts within my area of } \\
\text { speciality, provided I can reread difficult sections }\end{array}$ & 30 & 64 \\
\hline R 5 & B2 & $\begin{array}{l}\text { I can identify the type of technical text such as reports articles, letters, web } \\
\text { pages and instructions. }\end{array}$ & 64 & 32 \\
\hline R 6 & B2 & $\begin{array}{l}\text { I can adapt my style and speed of reading to different texts when consulting } \\
\text { reference sources selectively. }\end{array}$ & 29 & 63 \\
\hline R 7 & $\mathrm{C} 1$ & $\begin{array}{l}\text { I can understand in detail highly specialized texts and complex factual } \\
\text { documents in my academic or professional field, such as technical manuals, } \\
\text { project descriptions, legal contracts and research reports. }\end{array}$ & 15 & 61 \\
\hline R 8 & $\mathrm{C} 2$ & $\begin{array}{l}\text { I can understand and interpret critically virtually all forms of the written lan- } \\
\text { guage including abstract, structurally complex, or specialised academic texts. }\end{array}$ & 15 & 48 \\
\hline R 9 & $\mathrm{C} 2$ & $\begin{array}{l}\text { I can understand a wide range of long and complex texts, appreciating subtle } \\
\text { distinctions of style and purpose. }\end{array}$ & 16 & 61 \\
\hline \multicolumn{5}{|c|}{ READING CORRESPONDENCE } \\
\hline $\mathrm{R} 10$ & A1 & $\begin{array}{l}\text { I can understand short simple greetings and messages e.g. on birthday cards, } \\
\text { party invitations or SMS phone messages. }\end{array}$ & 93 & 5,2 \\
\hline R11 & A2 & $\begin{array}{l}\text { I can understand simple personal letters giving or requesting information } \\
\text { about everyday life or offering an invitation. }\end{array}$ & 92 & 6,5 \\
\hline $\mathrm{R} 12$ & A2 & $\begin{array}{l}\text { I can understand short simple messages from people who share my interests } \\
\text { (e-mails, webchats, postcards or short letters from pen-friends). }\end{array}$ & 80 & 17 \\
\hline $\mathrm{R} 13$ & A2 & $\begin{array}{l}\text { I can understand basic information in routine letters and e-mails on familiar } \\
\text { topics. }\end{array}$ & 88 & 9,3 \\
\hline R14 & B1 & I can understand simple messages, standard letters and e-mails. & 86 & 12 \\
\hline
\end{tabular}




\begin{tabular}{|c|c|c|c|c|}
\hline $\mathrm{R} 15$ & B2 & $\begin{array}{l}\text { I can read letters, faxes and e-mails, on topics within my areas of academic or } \\
\text { professional speciality and readily grasp the essential points. }\end{array}$ & 41 & 53 \\
\hline R16 & $\mathrm{C} 1$ & I can understand any correspondence given the occasional use of a dictionary. & 52 & 38 \\
\hline \multicolumn{5}{|c|}{ READING FOR ORIENTATION } \\
\hline R17 & A2 & $\begin{array}{l}\text { I can find specific predictable information in simple everyday material such } \\
\text { as information leaflets. }\end{array}$ & 75 & 21 \\
\hline $\mathrm{R} 18$ & A2 & $\begin{array}{l}\text { I can skim small advertisements in newspapers, locate the heading or column } \\
\text { I want and identify the most important pieces of information (price and size } \\
\text { of apartments, cars, computers). }\end{array}$ & 80 & 14 \\
\hline R19 & A2 & $\begin{array}{l}\text { I can understand words and phrases on simple everyday signs and notices } \\
\text { (e.g., exit, no smoking, danger, days of the week, times). }\end{array}$ & 81 & 19 \\
\hline $\mathrm{R} 20$ & B1 & $\begin{array}{l}\text { I can understand the most important information in simple informative texts, } \\
\text { such as web pages and brochures relating to my professional field. }\end{array}$ & 69 & 31 \\
\hline R21 & B1 & $\begin{array}{l}\text { I can find and understand relevant information in everyday material, such as } \\
\text { standard letters,application forms and short official documents. }\end{array}$ & 54 & 41 \\
\hline R22 & B1 & $\begin{array}{l}\text { I can scan longer texts in my field to gather information from different texts } \\
\text { or parts of a text in order to complete a specific task. }\end{array}$ & 26 & 66 \\
\hline R23 & B1 & $\begin{array}{l}\text { I can scan and skim longer texts in order to locate specific factual informa- } \\
\text { tion. }\end{array}$ & 41 & 52 \\
\hline $\mathrm{R} 24$ & B2 & $\begin{array}{l}\text { I can read many kinds of texts at different speeds according to reading purpo- } \\
\text { se and type of texts. }\end{array}$ & 38 & 55 \\
\hline $\mathrm{R} 25$ & B2 & $\begin{array}{l}\text { I can quickly scan through long and complex texts on a variety of topics to } \\
\text { locate specific information or decide if closer study is worthwhile. }\end{array}$ & 18 & 59 \\
\hline $\mathrm{R} 26$ & B2 & $\begin{array}{l}\text { I can quickly look through a manual finding and understanding relevant } \\
\text { explanations for a specific problem. }\end{array}$ & 44 & 46 \\
\hline $\mathrm{R} 27$ & $\mathrm{C} 1$ & $\begin{array}{l}\text { I can quickly grasp the content and relevance of news items, articles and } \\
\text { reports on a wide range of professional topics, deciding whether closer study } \\
\text { is worthwhile. }\end{array}$ & 25 & 61 \\
\hline \multicolumn{5}{|c|}{ READING FOR INFORMATION } \\
\hline $\mathrm{R} 28$ & A2 & $\begin{array}{l}\text { I can identify key information in simple written material such as letters, } \\
\text { brochures and short articles describing events. }\end{array}$ & 86 & 12 \\
\hline R29 & A2 & $\begin{array}{l}\text { I can understand simple informational material if there is pictorial support } \\
\text { (e.g., posters, catalogues, advertisements). }\end{array}$ & 85 & 15 \\
\hline R30 & B1 & $\begin{array}{l}\text { I can understand the main points in short newspaper articles about current and } \\
\text { familiar subjects. }\end{array}$ & 89 & 11 \\
\hline R31 & B1 & $\begin{array}{l}\text { I can identify line of argument and the main conclusions in clearly signalled } \\
\text { argumentative texts related to my academic or professional field. }\end{array}$ & 44 & 50 \\
\hline
\end{tabular}




\begin{tabular}{|c|c|c|c|c|}
\hline $\mathrm{R} 32$ & B1 & $\begin{array}{l}\text { I can recognise, though not necessarily in detail, the line of argument in the } \\
\text { treatment of the issue presented distinguishing between facts and opinions }\end{array}$ & 57 & 35 \\
\hline R33 & B1 & I can assess a writer's purpose and attitude in articles and web pages. & 32 & 58 \\
\hline R34 & B2 & $\begin{array}{l}\text { I can read and understand articles and reports in which writers express opi- } \\
\text { nions or viewpoints (e.g., art reviews, political commentary). }\end{array}$ & 51 & 40 \\
\hline R35 & B2 & $\begin{array}{l}\text { I can understand articles on specialized topics occasionally using a dictionary } \\
\text { and other appropriate reference resources to check specific vocabulary. }\end{array}$ & 60 & 36 \\
\hline R36 & B2 & $\begin{array}{l}\text { I can obtain information, ideas and opinions from specialized sources within } \\
\text { my academic or professional field. }\end{array}$ & 42 & 54 \\
\hline R37 & $\mathrm{C} 1$ & $\begin{array}{l}\text { I can extract information, ideas and opinions from highly specialised texts in } \\
\text { my own field, for example research reports. }\end{array}$ & 23 & 65 \\
\hline $\mathrm{R} 38$ & $\mathrm{C} 1$ & $\begin{array}{l}\text { I can understand lenghty, complex reports, analyses and commentaries where } \\
\text { opinions, and professional viewpoints are discussed. }\end{array}$ & 10 & 57 \\
\hline \multicolumn{5}{|c|}{ READING INSTRUCTIONS } \\
\hline R39 & A1 & I can follow short, simple written directions (e.g. to go from $\mathrm{X}$ to $\mathrm{Y}$ ) & 79 & 21 \\
\hline $\mathrm{R} 40$ & A1 & I can follow simple and clear instructions that have clear pictures. & 91 & 6,9 \\
\hline R41 & A2 & $\begin{array}{l}\text { I can understand important instructions on public signs and machines (e.g. } \\
\text { How to use a telephone). }\end{array}$ & 90 & 9,9 \\
\hline R42 & A2 & $\begin{array}{l}\text { I can understand messages or simple help indications in computer program- } \\
\text { mes. }\end{array}$ & 77 & 21 \\
\hline R43 & B1 & $\begin{array}{l}\text { I can understand safety instructions and regulations when expressed in simple } \\
\text { language (e.g., laboratory instructions). }\end{array}$ & 74 & 25 \\
\hline R44 & B1 & $\begin{array}{l}\text { I can understand clearly written straighforward instructions (e.g., for using a } \\
\text { piece of equipment, for answering questions in an exam). }\end{array}$ & 58 & 41 \\
\hline R45 & B2 & $\begin{array}{l}\text { I can distinguish the difference in meaning among warnings, cautions and } \\
\text { dangerous levels. }\end{array}$ & 50 & 45 \\
\hline R46 & B2 & $\begin{array}{l}\text { I can understand lengthy complex instructions in my field, including details } \\
\text { on conditions or warnings, provided I can reread difficult sections. }\end{array}$ & 22 & 68 \\
\hline R47 & $\mathrm{C} 1$ & $\begin{array}{l}\text { I can understand long complex instructions, for example for the use of a new } \\
\text { piece of equipment, related to my job or field of interest, provided I have } \\
\text { enough time to reread them and to consult very specialised terms. }\end{array}$ & 16 & 60 \\
\hline R48 & $\mathrm{C} 1$ & $\begin{array}{l}\text { I can understand detailed and complex manuals for a new machine or proce- } \\
\text { dure, whether or not they relate to my own area of speciality, provided I can } \\
\text { reread difficult sections. }\end{array}$ & 21 & 63 \\
\hline \multicolumn{5}{|c|}{ READING REPORTS AND ARTICLES } \\
\hline R49 & A1 & I can understand simple reports if there is pictorial support. & 86 & 12 \\
\hline
\end{tabular}




\begin{tabular}{|c|c|c|c|c|}
\hline R50 & A1 & $\begin{array}{l}\text { I can understand pictorial illustrations and their labels in a technical report in } \\
\text { my field }\end{array}$ & 88 & 12 \\
\hline R51 & $\mathrm{A} 2$ & $\begin{array}{l}\text { I can pick out the key facts and conclusions from the summary of a report in } \\
\text { my field }\end{array}$ & 68 & 27 \\
\hline R52 & B1 & I can identify the different type of reports. & 55 & 43 \\
\hline R53 & B1 & $\begin{array}{l}\text { I can recognize the different parts of engineering reports and articles: abstract, } \\
\text { introduction, methods, discussion, conclusions, acknowlegements and refe- } \\
\text { rences. }\end{array}$ & 44 & 45 \\
\hline R54 & B2 & I can understand technical reports within my speciality & 27 & 73 \\
\hline R55 & $\mathrm{C} 1$ & $\begin{array}{l}\text { I can uderstand detailed and complex reports within my field with the occatio- } \\
\text { nal use of an dictionary. }\end{array}$ & 30 & 53 \\
\hline R56 & $\mathrm{C} 2$ & $\begin{array}{l}\text { I can understand detailed and complex reports whether or not the topic relates } \\
\text { to my own area of speciatlity. }\end{array}$ & 0 & 82 \\
\hline R57 & $\mathrm{C} 2$ & $\begin{array}{l}\text { I can apply the criteria to determine a well researched and written article or } \\
\text { report }\end{array}$ & 9,1 & 75 \\
\hline \multicolumn{5}{|c|}{ READING STRATEGIES } \\
\hline R58 & A2 & $\begin{array}{l}\text { I can use the general context and the topic of a short text to derive the proba- } \\
\text { ble meaning of a new word. }\end{array}$ & 73 & 23 \\
\hline R59 & B1 & I can use visuals to find out the meaning of unknown technical terms & 65 & 33 \\
\hline R60 & B1 & $\begin{array}{l}\text { I can derive the meaning of unknown words from the context on topics rela- } \\
\text { ted to my field of interest. }\end{array}$ & 46 & 48 \\
\hline R61 & B1 & $\begin{array}{l}\text { I can check unknown words in a dictionary and select the appropriate me- } \\
\text { aning according to context. }\end{array}$ & 64 & 33 \\
\hline R62 & B2 & $\begin{array}{l}\text { I can skim a specialised text (e.g. reports and articles) and predict its content } \\
\text { from the title, headings, subheadings and figures }\end{array}$ & 29 & 57 \\
\hline R63 & B2 & $\begin{array}{l}\text { I can use a variety of strategies to understand a complex text, including word } \\
\text { building, grammatical and other contextual clues. }\end{array}$ & 16 & 58 \\
\hline R64 & $\mathrm{C} 1$ & $\begin{array}{l}\text { I can use textual, contextual, grammatical and lexical clues to achieve com- } \\
\text { prehension of a text on an unfamiliar topic and to infer the writer's intentions. }\end{array}$ & 16 & 71 \\
\hline
\end{tabular}

